\title{
THE TEMPLE OF EPICURIOUS APOLLO AT BASSAE: PRESERVE THE STONE OR UNCOVER ITS TRUE NATURE?
}

\section{KAPADOUKAKI Eva ${ }^{1}$ SOUMAS Michail ${ }^{1}$}

1 MA Architecture National Technical University of Athens 2017; e.kapadoukaki@gmail.com https://orcid.org/0000-0003-2345-7655

1 MA Architecture National Technical University of Athens 2017; msoumas@icloud.com https://orcid.org/0000-0001-7330-9912

\section{Introduction}

The temple of Apollo Epicurious built around the last quarter of the 5th century B.C. in the mountainous landscape of Bassae (Phigaleia, Peloponnese, Greece) is the first greek monument to be included in the UNESCO World Heritage List in 1986. A temple remarkable for its archaic features (elongated stylobate $14.5 \times 38.3 \mathrm{~m}-15$ columns on the longer flanks and 6 on the facade, NS orientation) combined with daring innovations. Its architect, Ictinus, managed to creatively surpass the strict character of the Doric order merging Ionic half-columns with an Ionic frieze inside the cella and combining it with the earliest known Corinthian capital (documented by C.H.Hallerstein in 1812) replacing the deity's statue. Behind the free-standing column, the adyton is illuminated through a side door. The temple stands as an exceptional case in architectural history, recomposing the Attic architectural model into an original creation of human ingenuity. Today it stands as an extreme case of a monument in need of both material and conceptual conservation-restoration. 


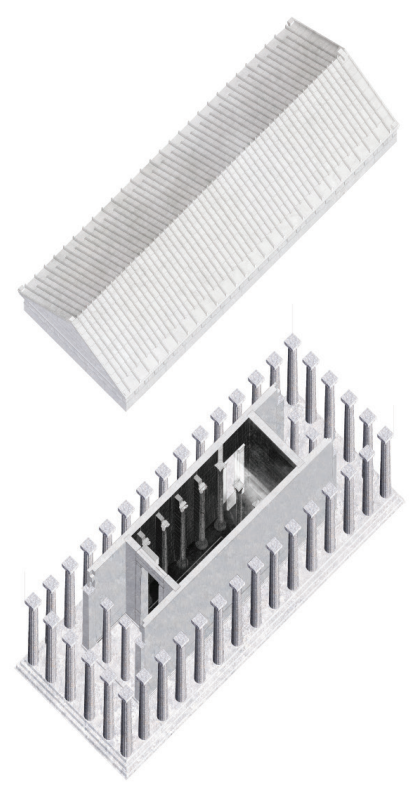

Fig. 1 Graphic Reconstruction of the Temple (Kapadoukaki E., Soumas M., 2017)

\section{Materiality}

The temple, being isolated in the mountainous landscape, has managed to finally be one of the bestpreserved structures of Antiquity in terms of the amount of original material (60\%) that remains in situ, undergone no intervention until the 20th century. It is built mostly of local sedimentary limestone (Maastrichtian), originating from the rock formation in the immediate vicinity of the monument. The stone, set in the high altitude of $1130 \mathrm{~m}$ a.s.l., suffers severe deterioration mainly due to frost in the winter and large diurnal temperature width in autumn-spring (8-0oC, humidity $80-100 \%$, summer $20 \mathrm{oC}$-humidity $60-30 \%$, generally NW or NE winds). The numerous discontinuities, weak planes or superimposed weak veins facilitate ingress of rainwater ( $\mathrm{CO} 2$ included) within the pores and external mechanical stresses such as earthquakes have a shear effect whenever discontinuities run parallel to the exposed surface. The result is a capillary cracking pattern, gradually widening and ending up in detachment of flat pieces (Theoulakis, 1995). Today's conservation-restoration works combine stabilising clay mixture, pozzolanic cement grout and lead sheets (C.C.T.A.E., Papadopoulos, 2015). 

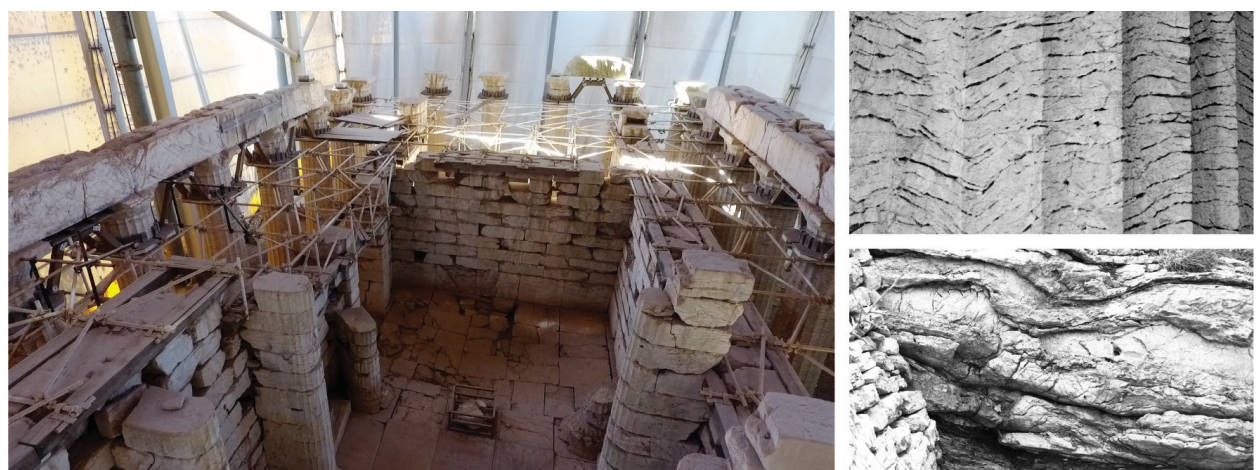

Fig. 2 Deterioration Modes of the Stone (personal archive of the authors, 2017)

The contemporary synthetic PVC canopy levels out the temperature fluctuations $(+1-20 \mathrm{C})$ but has a serious misleading effect upon the building's features. The temple's colour as seen in open-air conditions has a wide tone variety from grey to orange and violet, even with deep blue shadows (F.A. Cooper, 1996) meant to stay naked, without stucco or paint. While today's scattered parts of the temple on site are decolorised by white spots due to the microfauna, the standing parts of the temple undergo a very different discoloration. The shelter filters the sunlight, applying a yellowish shade on the original grey stone, giving an extremely false impression to the visitor, while the new stone supplements, which are used for the conservation-restoration, are whiter.

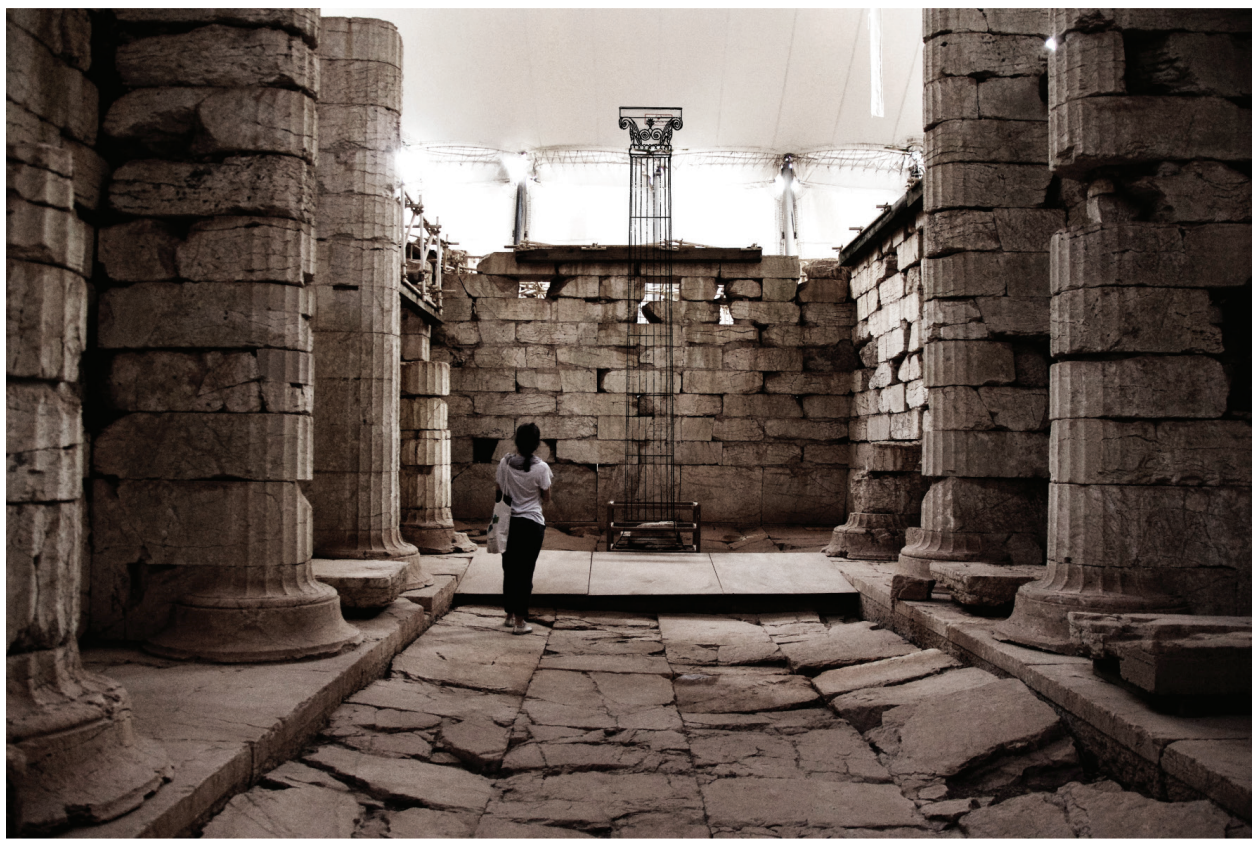

Fig. 3The Materiality of the Temple, Cella (Kapadoukaki E., Soumas M., 2017) 

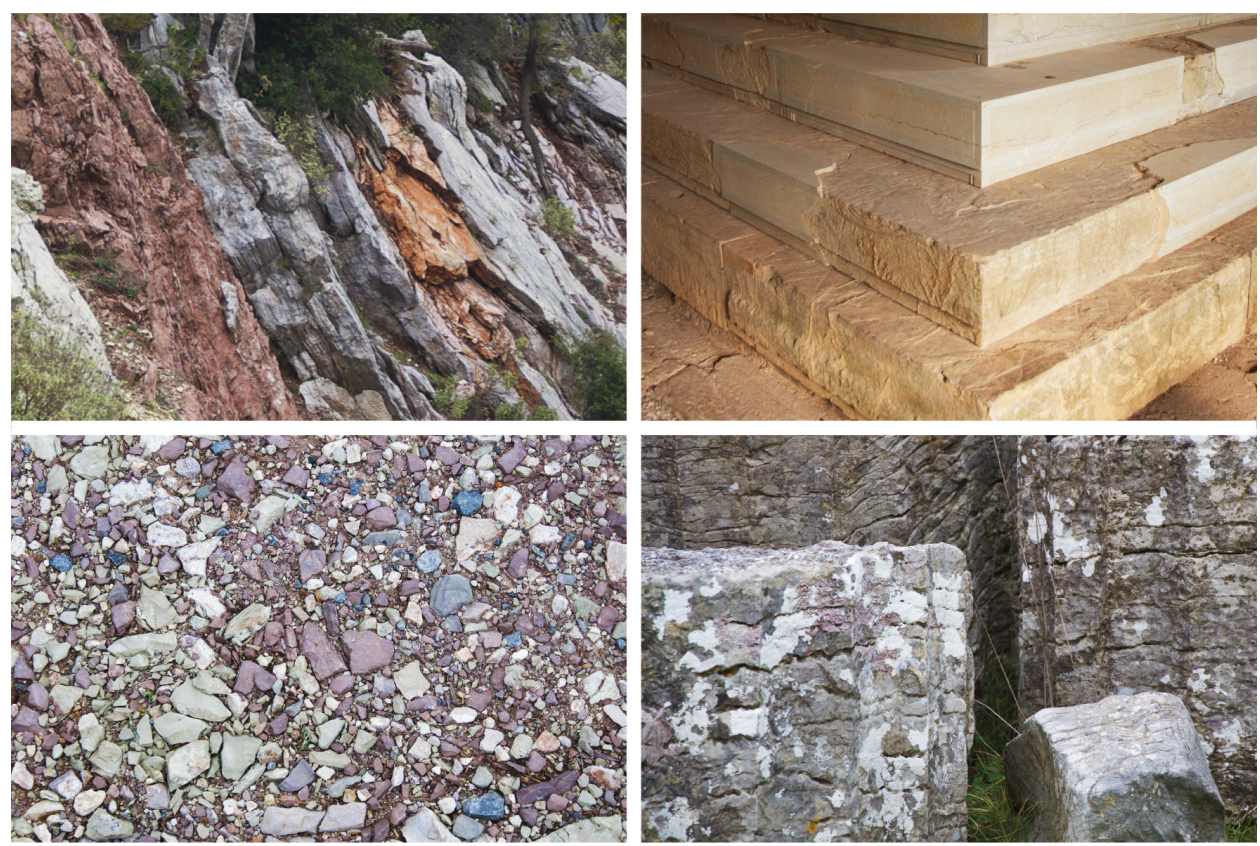

Fig. 4 The Local Limestone, Colours and Textures (personal archive of the authors, 2017)

The current conservation-restoration program has maintained the building's original structural system using reversible but strictly conservative methods (in the spirit of the Venice Charter 1964). Its documentation and evaluation criteria took place in 1990 but contemporary conditions including climate change suggest a need for new considerations. Experimentation according to this extreme case of material erosion and hostile environment is necessary. The authors suggest a turn to synthetic biology as it already has its footprint in architecture and archaeology. Instead of repairing the authentic parts by hand with new differentiated patched stone, genetically modified bacteria can be designed and injected in the cracks producing the exact same Maastrichtian limestone. Filling deep cracks would be far more accurate, and the new monolithic result will re-establish the integrity of each member having mechanical and aesthetic characteristics inherent to the building. This conservation-restoration method is technically doable and philosophically compatible with the monument's apparent presentday value of newness and art-value as a whole. 

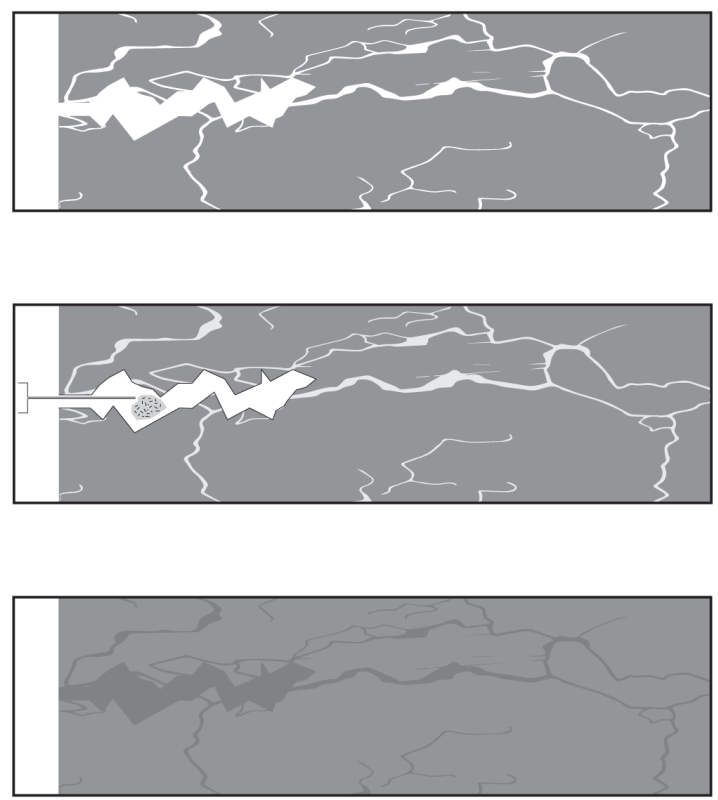

Fig. 5 Visualisation of the Proposed Bacteria-Based Reconstruction (Kapadoukaki E. \& Soumas M., 2017)

\section{Architectural Elements}

The temple's first critical viewpoint is a panoramic view from the serpentine walkway along the slope of Mountain Kotilon, a hill without a peak, with a continuous knoll which shapes the top plateau where the archaic temples of Artemis and Aphrodite are placed. This frame reveals the linearity of the low jagged ridge, "broken" by the temple itself. Together, they have an axial effect facing north, forming a continuous facade in front of the Arcadian mountains. The second is from the ancient SW route from Phigaleia (Pausanias' route) where one can view the temple constantly as a singular object or destination, having only the sky as a background. This frame reveals the slightly horned cleft where the temple is set, reorganizing the rocky ridge sculpturally. Upon this ridge lies also the archaic temple of Apollo. The classical temple differs in design principles of scale and setting but it has a deep relevance to the archetype (engaged semi-columns inside the cella; see: Kelly N., 1995). The research presents a new detailed and systematic analysis of the landscape's morphology. The authors regard it as a special case study combining "cultural and natural heritage" because of this truly unique relationship of manmade and natural. The temple with its surrounding landscape should be regarded as one inseparable monument. The modern observer has to approach it the same way in order to perceive the creative mind and conceptual breadth behind this man-centered design, instead of regarding it as a merely abstract or pictorial construction. 


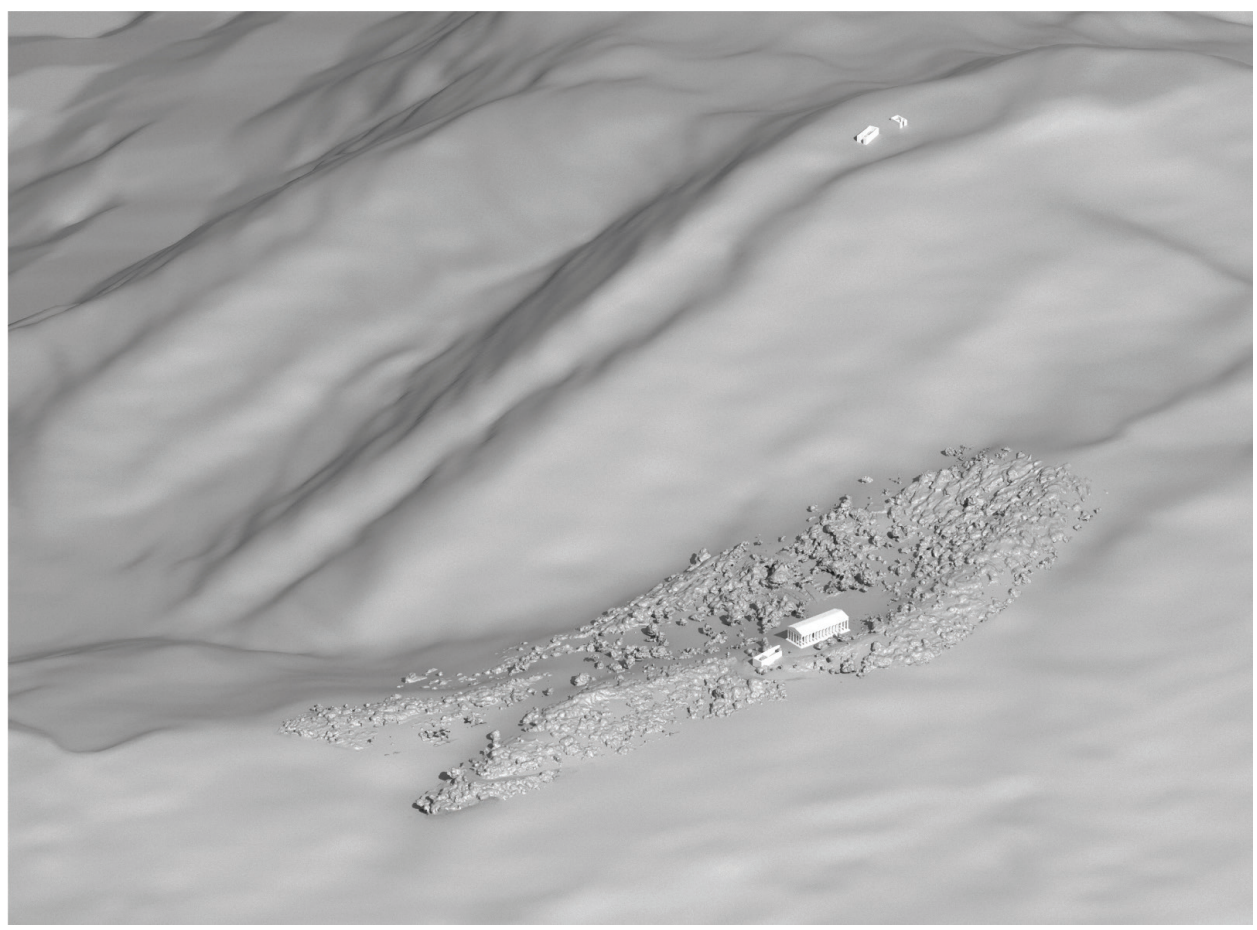

Fig. 6 The Temple in his Landscape (documentation-visualisation by Kapadoukaki E., Soumas M., 2017)

The present dilemma is that of keeping the temple covered destroying its connection with the stone ridge, or letting it stand visible in its landscape conserving its integrity as a whole artifact. The current management plan stands weak as there has been no alternative suggestion since 1987, supporting the "temple-canopy differentiated image" concept. Regarding the authors' proposal for a new shelter, the selection of transparent material for keeping the temple visible is considered necessary. While side covering isn't critical for temperature balancing, the short flanks of the temple can and should have their original visual contact with the ridge. As the temple's plan is open and inviting but also sets a limit as the eye slips between the column shafts and tries to enter the cella, the proposed superstructure is offering a similar filtered view macroscopically, modifying the circular column plan into a hollow semi-circle. It's hollow in order to accommodate each of the full-height columns during their conservation-restoration (current restoration methodology, C.C.T.A.E., Papadopoulos, 2015). This way not only they are respectively placed to their relative position helping the observer to visually reform the temple, but also one can examine each column as an independent sculptural unit. Vertical blade-like beams assemble together the long stripes of glass, as an abstract reference to the flutings. Furthermore, the overhead crane for the temple's parts relocation is integrated fully into the shelter's structure. 


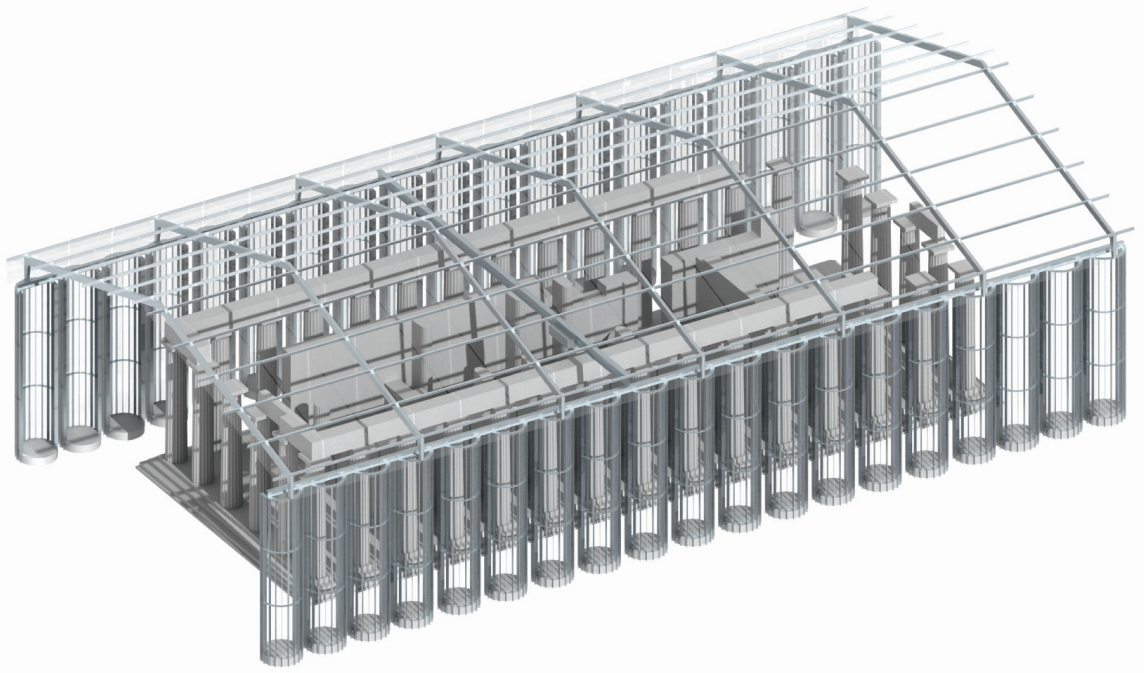

Fig. 7 The Design Proposal for the New Shelter (Kapadoukaki E., Soumas M., 2017)
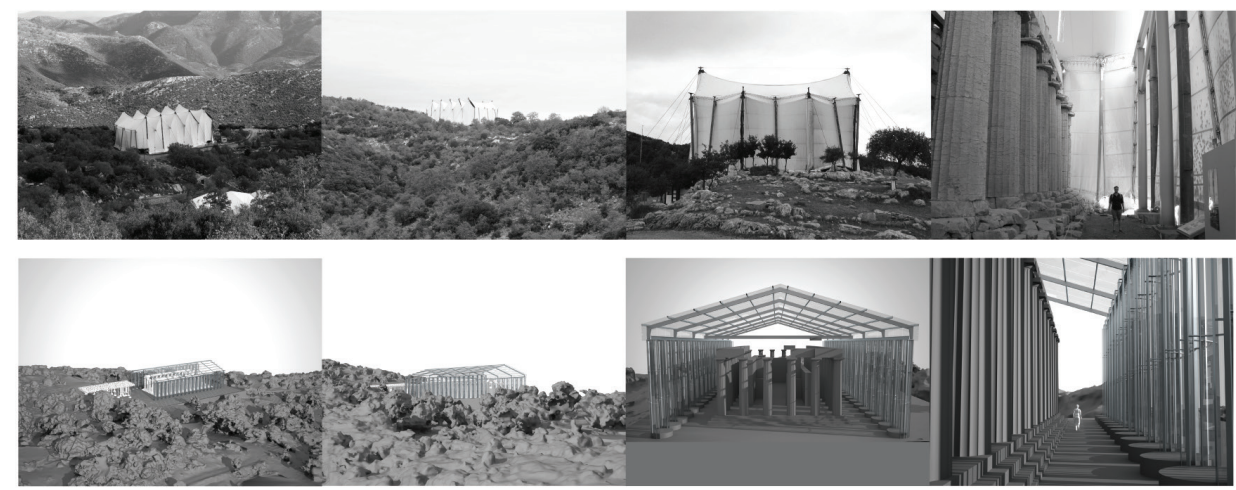

Fig. 8 Comparison of Current and Proposed Shelter, Critical Views (Kapadoukaki E., Soumas M., 2017) 


\section{Bibliography}

Committee of Conservation of the Temple of Apollo Epicurious (C.C.T.A.E.) (Ed.). (1996). 1st Meeting for the Conservation of the Temple of Epicurious Apollo, Athens 18-20 March 1995, Proceedings. Athens: Ministry of Culture.

Cooper F.A. (1996). The temple of Apollo Bassitas I: The Architecture, Princeton: American School of Classical Studies at Athens.

Kelly N. (1995). The Archaic Temple of Apollo at Bassai: Correspondences to the Classical Temple. In: Hesperia: The Journal of the American School of Classical Studies at Athens, Vol.64, No.2, Apr-Jun.1995, pp.227-277.

Papadonopoulos K. (1995). The Temple of Apollo Epicurious at Bassae: Structural Restoration Study

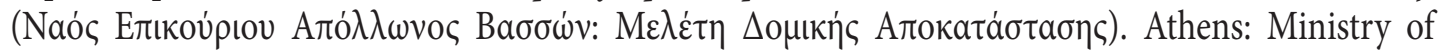
Culture, C.C.T.A.E.

Papadopoulos K. (2015).The Temple of Apollo Epicurious at Bassae: Restoration of the Long Flanks

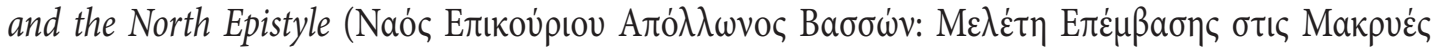

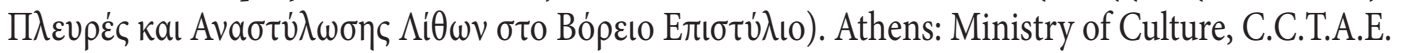

Roux G. \& von Hallerstein K.H. (1976). Le temple de Bassae: relevés et dessins du temple d’Apollo à Bassae, conservé à la Bibliothèque nationale et universitaire de Strasbourg. Strasbourg: La Bibliotèque Nationale et Universitaire de Strasbourg.

Scully V.J. (1962). The earth, the temple, and the gods: greek sacred architecture. New Haven: Yale University Press.

Svolopoulos D. (1995). The Temple of Apollo Epicurious at Bassae: Architectural Study (Naóc Eлıкoúpıov

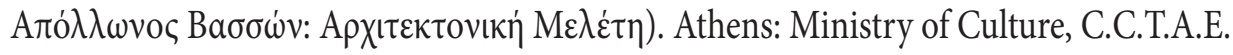

Theoulakis P. (1995). The Temple of Apollo Epicurious at Bassae: study for the conservation of the

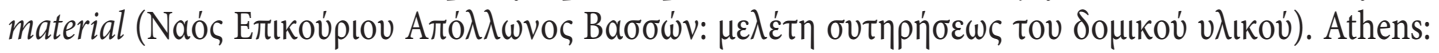
Ministry of Culture, C.C.T.A.E. 